\title{
Real-Time Fine-Scale Measurement of Water Quality Parameters Along the Bagmati River in the Kathmandu Valley
}

\author{
M. P. Adhikari*†, N. B. Rawal* and N. B. Adhikari** \\ *Central Department of Chemistry, Tribhuvan University, Kirtipur 44613, Kathmandu, Nepal \\ **Department of Electronics and Computer Engineering, Pulchowk Campus, Institute of Engineering, Tribhuvan \\ University, Kathmandu 44700, Nepal \\ $†$ Corresponding authors: M. P. Adhikari; mandira43@ hotmail.com
}

\section{Nat. Env. \& Poll. Tech.} Website: www.neptjournal.com

Received: $28-07-2020$

Revised: $30-09-2020$

Accepted: 09-10-2020

Key Words:

Mobile sensor system

Water quality

Bagmati river

Water pollution

\begin{abstract}
Real-time fine-scale data was collected along the Bagmati River, in Kathmandu Valley, using mobile and fixed sensor system during the winter season. The water quality parameters; $\mathrm{pH}$, conductivity, total dissolved salt (TDS), salinity, oxygen reduction potential (ORP), dissolved oxygen (DO), and turbidity were measured in the space domain using a fixed sensor and mobile sensor (small rafting boat loaded with sensor) systems. The water quality parameters from the fixed sensor system revealed that the Bagmati River was comparatively less polluted upstream from Gokarna to Tilganga sites and molecular oxygen present in the water was enough to decompose organic pollutants. However, the water quality downstream from Tinkune to Balkhu sites was degraded drastically making it unfit for living organisms. Temporal variation of water quality attributes that human activity significantly enhanced pollutants which severely degraded the water quality in the daytime. The fine-scale space domain heat map data of the mobile sensor system also suggested that the water quality continuously deteriorated from Shankhamul to Sundarighat sites. The ORP value was always negative and decreased with downflow and becomes $-263 \mathrm{mV}$ near the Sundarighat Bridge. The mixing of tributaries and increment of solid waste and untreated sewer along the river enhanced pollutants excessively and decreased oxygen level to zero. The results attributed that decomposition of the sewer by microorganism consumed almost all oxygen which produced volatile compounds and generated malodorous odor downstream of Bagmati River.
\end{abstract}

\section{INTRODUCTION}

Bagmati River originates from the Shivapuri Hill and passes through different culturally important places of the Kathmandu Valley. It enters the valley at Sundarijal and ends at Chovar. It stretches about $51 \mathrm{~km}$ inside the Kathmandu Valley and it has a catchment area of about 678 square $\mathrm{km}$ (Shrestha \& Tamrakar 2012). It is immensely important culturally, historically, biologically, and geologically among the river system of the Kathmandu Valley. It is one of the holy rivers of Hindu, hence, culturally and historically, there are no alternatives of river water for the Hindu people. People use this river for taking bath and also for paying homage to their ancestors and gods and take small quantities of water to their home for use in rituals. In addition, some people living near the bank are still using Bagmati River water for bathing, washing vegetables, utensils, and clothes; for agriculture, industry, and irrigation purposes (Wolfe 2000, Milner et al. 2015). Although the Bagmati River is immensely important, most of the portion in Kathmandu Valley was found to be critically polluted (Paudyal et al. 2016, Mehta \& Rana 2017, Adhikari et al. 2019, Sharma et al. 2020).
There are five major tributaries, namely, Manohara, Dhobi, Tukucha, Bishnumati, and Balkhu Khola in the Kathmandu Valley. Hence, tributaries significantly affect the water chemistry of the Bagmati River inside the Kathmandu Valley (Adhikari \& Sah 2017). In addition, the uncontrolled and mismanaged growth of the population in the Kathmandu Valley is destroying the palatability of river water. People are directly discharging untreated sewage and personal garbage into the river. The river is converting into one of the easily accessible dumping sites for solid wastes and untreated domestic, industrial, and agricultural effluents (Kannel et al. 2007, Mishra et al. 2017, Pratum et al. 2019). It was reported that Bagmati River water is in pristine condition upstream, however, downstream it is critically polluted (Regmi 2013, Mishra et al. 2017, Sharma et al. 2020). Shrestha et al. (2015) observed DO concentration of more than $10 \mathrm{mg} . \mathrm{L}^{-1}$ upstream and less than $1 \mathrm{mg} . \mathrm{L}^{-1}$ downstream of Bagmati River in Kathmandu Valley. The river water was grey color upstream while it was black color downstream (Adhikari et al. 2019, Mehta \& Rana 2017). Although numerous campaigns were conducted to clean the Bagmati River, the stinking smell and blackish 
color of the water are still existing. These characteristics of river water and the ecology of the Bagmati River threaten not only humans but also living organisms that rely on the river because pollutants including toxic elements present in the river water potentially affect the aquatic ecosystem (Tripathee et al. 2016, Mahmud et al. 2019). Hence, the determination of the level of pollutants and identification of the source of pollutants is important to rectify the problem and implement the action effectively. In traditional water quality monitoring systems, the water samples used to be collected and analyzed manually in a limited number in the laboratory. Therefore, there was a lack of freedom for the collection of enough data, hence real-time information in fine scales could not be delivered.

To resolve these queries, real-time and spatial profiling and characterizations of the pollutants using sophisticated mobile tracers and analyzers are of the highest need. Due to the exponential development of information technology, these days it becomes possible to track the pollutants in fine temporal and spatial scales. Besides collecting data from fixed monitoring stations, mobile tracers provide fine-scale analysis which would be the first experience in the case of the Nepalese River.

\section{MATERIALS AND METHODS}

The spatial variation of water quality parameters along the Bagmati River inside the Kathmandu Valley was conducted in December 2019 and January 2020 using a fixed sensor system. The portable Multi-Parameter Analyzer (Hanna, HI-9829) was used to collect data from different locations. It measures and logs real-time data of different physical parameters such as $\mathrm{pH}$, conductivity, salinity, total dissolved solids

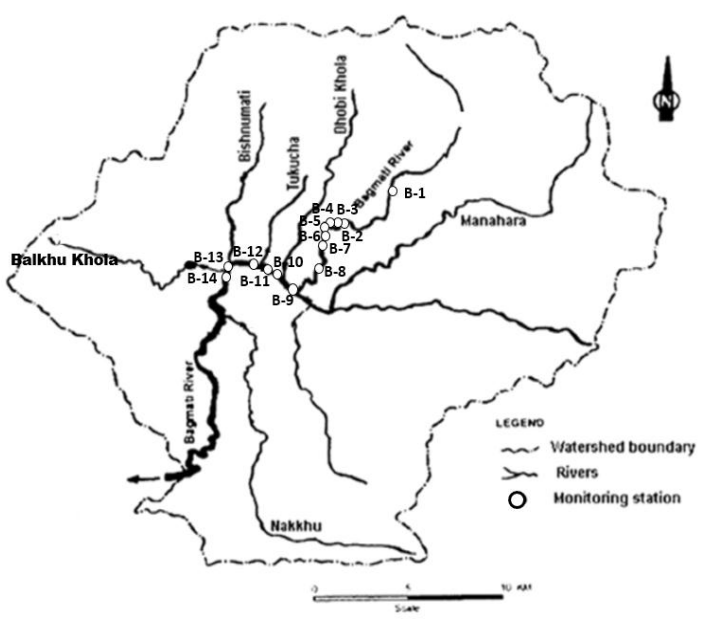

Fig. 1: Water quality monitoring station along the Bagmati river inside Kathmandu Valley.
(TDS), dissolved oxygen (DO), temperature, and turbidity. Data were continuously measured and logged in every 5 secs from 14 fixed stations (Fig. 1, Table 1) and at least 120 data sets were collected from each site. The observation was started from the farthest upstream site of Bagmati River, Gokarna site (B-1), which is located about $8 \mathrm{~km}$ from the entrance point (Sundarijal) of Bagmati River inside the Kathmandu Valley. This is a rural area and there are few local residents but lack of visible source of pollutants (Green 2003). The second and third sites were the B-2 and B-3 just upstream and downstream of Guheshwori Wastewater Treatment Plant, respectively. The B-2 and B-3 sites include the influence of residential as well as industrial areas such as wool dying companies, medical colleges, hotels, etc. The wastewater treatment plant collects wastewater from sewage lines and is treated before discharging into the Bagmati River. The next sampling site was the Guheshwori temple (B-4). The source of pollutants in this site is the activities of people along the banks of the river such as bathing, washing, conducting picnic, etc. The Gaurighat sampling site (B-5) represents the effects of the local residential area before entering the Pashupatinath temple site. Pashupatinath temple is the most holistically important Hindu temple of Nepal as well as the world. People take bath and use water for praying to gods and in cultural rituals. This place is also popular for the cremation of the human body. The ash remaining after the cremation is discharged directly into the river. The B-6 data was collected from Pashupatinath temple (Aryaghat

Table 1: Water quality data monitoring stations along the Bagmati River.

\begin{tabular}{|ll|}
\hline $\begin{array}{l}\text { Sample } \\
\text { name }\end{array}$ & Observation site \\
\hline B-1 & $\begin{array}{l}\text { Gokarna Temple: } 8 \text { km distance from the entrance of Bag- } \\
\text { mati River in Kathmandu Valley }\end{array}$ \\
B-2 & Upstream of Guheshwori Wastewater Treatment Plant \\
B-4 & Downstream of Guheshwori Wastewater Treatment Plant \\
B-5 & Guheshwori Temple \\
B-6 & Pashupatinath Temple (Aryaghat) \\
B-7 & Tilganga: Downstream of Pashupatinath Temple \\
B-8 & Tinkune (Min Bhawan) \\
B-9 & Shankhamul: Just downstream of Manohara confluence \\
B-10 & Dhobikhola: Just downstream of Dhobikhola confluence \\
B-11 & Thapathali: Just before the Bagmati Bridge \\
B-12 & Tukuchakhola: Just downstream of the Tukuchakhola \\
B-13 & Bishnumatikhola: Just downstream of Bishnumatikhola) \\
B-14 & Balkhukhola: Just downstream of Balkhukhola confluence \\
\hline
\end{tabular}


site). Pashupatinath area is bypass through a tunnel for the discharge of untreated wastewater and effluent from the treatment plant and are discharged at the Tilganga area into the Bagmati river (Green 2003). Next data was collected at Tilganga (B-7). The data was collected just downstream of discharge of the Guheshwori Wastewater Treatment Plant. The sampling site B-7 was the Tinkune. It was observed that solid waste and sewer lines connected directly to the river and noticeably dark and turbid water was observed from this site. The remaining observation sites were selected for the determination of the effect of tributaries on the Bagmati River. The observation sites B-9, B-10, B-12, B-13, and B-14 represent the confluence of Manahara, Dhobi, Tukuchha, Bishnumati, and Balkhu, respectively. Observation at Thapathali site R-11 represents the upstream of the most polluted tributary (Tukucha) of the Bagmati River (Bajracharya 2014). The daily and diurnal variations of the water quality parameter of the Bagmati River were observed at the Shankhamul site before mixing with the tributaries. The observation was conducted at effective working hours i.e., from 9:00 to 16:00 hour so that influence of domestic and industrial effluent on the Bagmati River could be clearly observed.

The next observation comprised the compilation of extremely minute and fine-scale real-time data using a mobile sensor system along the Bagmati River from Shankhamul to Sundarighat Bridge. The observation of spatio-temporal variation of water quality parameters was conducted on November 13, 2019, from 11:00 to $16: 30$. The portable Multi-Parameter Analyzer (Hanna, HI-9829) and Global positioning system (GPS) device were onboard in the small rafting boat. The data was measured and logged continuously every $5 \mathrm{sec}$ (a few meters). The boat was sailed slowly and possibly at the center of the water stream and center of the river (Fig. 2).

\section{RESULTS AND DISCUSSION}

At first, spatial and temporal variations of water quality parameters along the Bagmati River were determined using a fixed sensor system to find out the sources of pollutants. Then, the Bagmati River was characterized in the space domain using fine-scale real-time data from a mobile sensor system.

\section{Spatial Variation of Physiochemical Parameters along the Bagmati River}

The physicochemical characterization of water indicates the quality of river water. The data from 14 different sites (Fig. 1) was collected randomly at different times and dates in the winter season. The average and standard deviation of collected data were tabulated in Table 2 and some key parameters were plotted in Fig. 3 and 4. The observed temperature of river water was varied between 9 and 15 degrees Centigrade. The variation of observed temperature was consistent with the air temperature reported for different days by Weather Nepal (2020). Therefore, it was considered that there was a lack of thermal pollutants. The observed turbidity was as low as $51.22 \pm 10.63 \mathrm{FNU}$ at the B-1 site but higher than 300 FNU at other sites (Table 2, Fig 3a). The enhancement of turbidity at downflow may be either due to leaching of soil or mixing of domestic and industrial effluent in the river water during flowing (Costa et al. 2015). Fig. 3b shows that the $\mathrm{pH}$ of the river was almost neutral upstream up to the B-6 site and becomes more and more alkaline downstream from B-7. The slightly alkaline $\mathrm{pH}$ at downstream sites indicated that river water consists of a weak base such as carbonate and bicarbonates from soil or sand and/or ammonical compound from domestic sewage and agricultural run-off (Aggarwal \& Arora 2012) and/or microbial decomposition of organic matter (Sundararajan et al. 2018).

The spatial variation of conductivity, Oxidation Reduction Potential (ORP), and Dissolved Oxygen (DO) were plotted in Fig. 4 . The observed conductivity was less than $228.28 \pm 10.76 \mu \mathrm{S} / \mathrm{cm}$ till B-6 and that was more than two times at B-7 $(485.53 \pm 2.86 \mu \mathrm{S} / \mathrm{cm})$ then increased almost continuously from B-8 to B-14 sites (Fig. $4 \mathrm{a}$ ). The observed conductivity indicated that effluents of domestic and industrial pollutants were low upstream till B-6 but loading of municipal wastes from the residential area and tributaries enhanced conductive substances and increased conductivity downstream (Okeke \& Adinna 2013). Further, Table 2 showed that total dissolved solids (TDS) were low about $67.02 \pm 0.70 \mathrm{ppm}$ at B-1, and increased linearly till B-6 site then enhanced drastically after B-7, and it was almost

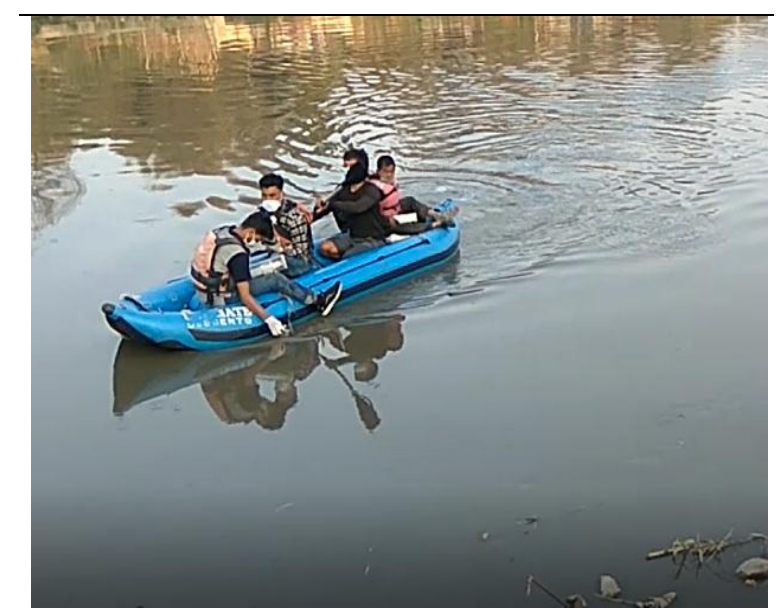

Fig. 2: Water quality data collection along Bagmati River using mobile tracing system (rafting boat loaded with measuring instrument). 


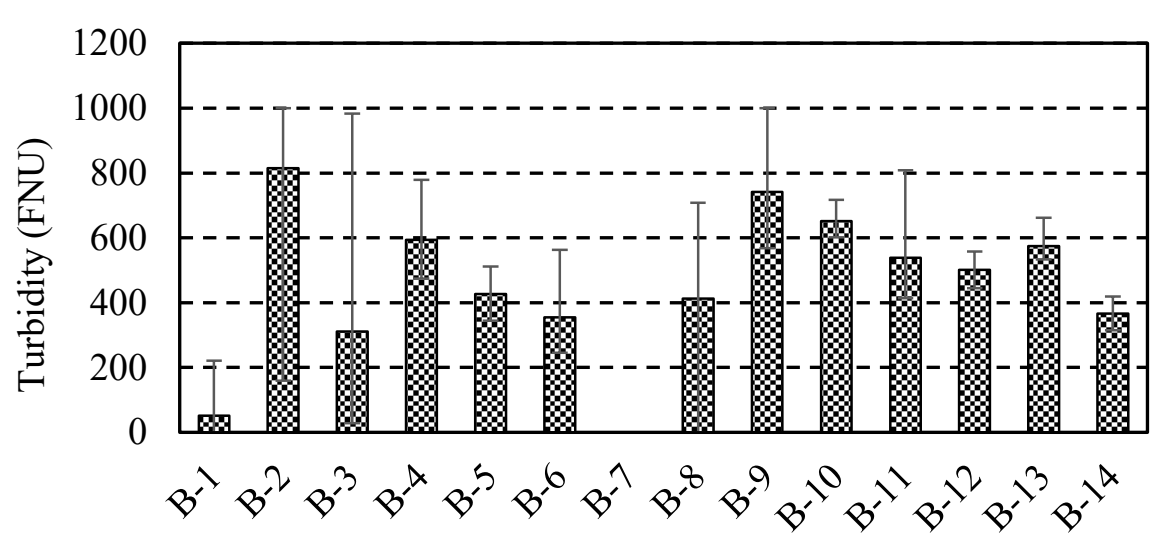

Sample number

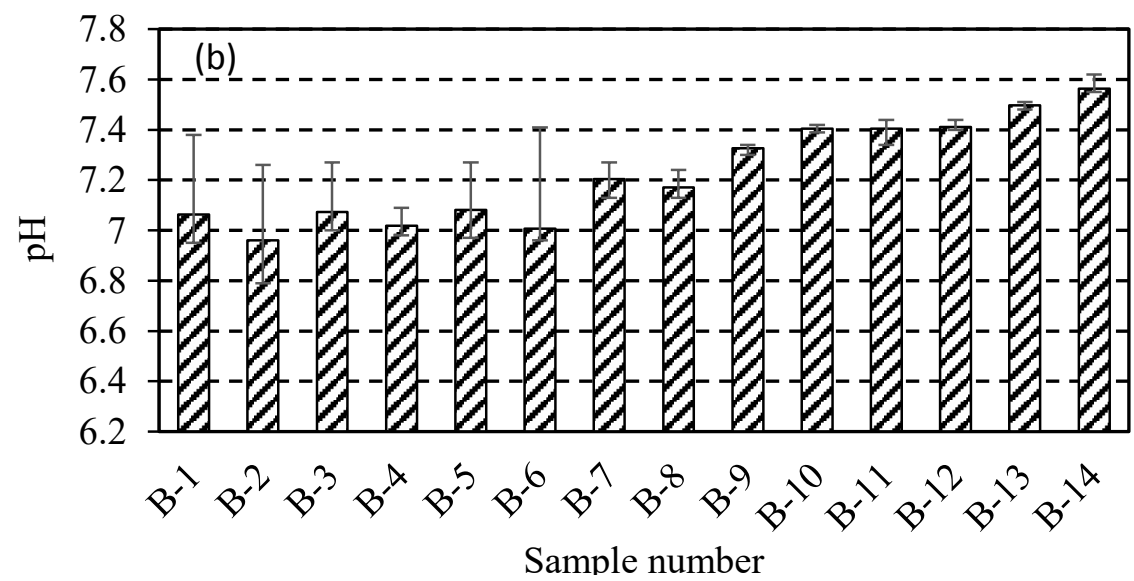

Fig. 3: Spatial variation of (a) Turbidity and (b) pH along the Bagmati River from Gokarna (B-1) to Balkhu (B-14) site.

seven-folds high at the end of the observation site (B-14). Similarly, salinity was less than 0.1 psu till the B-6 site but it enhanced continuously downstream and becomes 0.46 psu at the B-14 site. McCarthey et al. (2008) and Malla et al. (2015) reported that domestic and industrial wastewater is typically enriched in salts therefore inflow of municipal and industrial discharge enhanced the conductivity, salinity, and TDS of water. The oxidation-reduction potential (ORP) is a critical water quality parameter that measures the water disinfection potential. This parameter is most prominently used in wastewater treatment plants (Suslow 2004, Goncharuk et al. 2010). The presence of oxidizing agent (oxygen) increases the ORP value and a reducing agent (substrate or carbon and hydrogen-containing compound) decreases the ORP value. The observed ORP of river water varied differently between upstream and downstream (Fig. 4b). In the case of upstream, the ORP was positive and the potential was mostly more than $50 \mathrm{mV}$. However, the ORP value was negative and it ranged from -30 to -114 downstream. Suslow (2004) and Goncharuk et al. (2010) reported that the ORP value between +50 to $+250 \mathrm{mV}$ is useful for the degradation of an organic compound with free molecular oxygen and nitrification process. The ORP value between +50 and $-50 \mathrm{mV}$ is suitable for denitrification and between -50 and $-250 \mathrm{mV}$ is suitable for sulfide formation and biological phosphorus release. The negative ORP value suggested that the river water downstream consists of reducing agents from wastewater which may produce sulfide and biological phosphorus. Another most important parameter to determine the water quality is the Dissolved Oxygen (DO). At upstream, the DO concentration was within the acceptable limit (4-10 $\mathrm{ppm}$ ), however, it was less than $3 \mathrm{ppm}$ downstream except at B-12 and B-14 (Fig. 4c). The microbial decomposition of organic material utilized molecular oxygen which drastically decreases the DO in water (Okeke \& Adinna 2013). The DO concentration attributed that organic substance in the river water was low upstream which consumed a lesser amount of molecular oxygen. However, the enhanced organic substance downstream consumed a higher amount of molecular oxygen and reduced the DO concentration. All the results attributed 
Table 2: Water quality parameters measured along the Bagmati River at 14 observation sites.

\begin{tabular}{|c|c|c|c|c|c|c|c|c|c|}
\hline $\begin{array}{l}\text { Sample } \\
\text { number }\end{array}$ & $\begin{array}{l}\text { Tempera- } \\
\text { ture } \\
{\left[{ }^{\circ} \mathrm{C}\right]}\end{array}$ & $\begin{array}{l}\text { Turbidity } \\
{[\text { FNU] }}\end{array}$ & $\mathrm{pH}$ & $\begin{array}{l}\text { ORP } \\
{[\mathrm{mV}]}\end{array}$ & $\begin{array}{l}\text { Conductivity } \\
{[\mu \mathrm{S} / \mathrm{cm}]}\end{array}$ & $\begin{array}{l}\text { TDS } \\
{[\mathrm{ppm}]}\end{array}$ & $\begin{array}{l}\text { Salinity } \\
\text { [PSU] }\end{array}$ & $\begin{array}{l}\text { DO } \\
{[\mathrm{ppm}]}\end{array}$ & $\begin{array}{l}\text { No of } \\
\text { sam- } \\
\text { ple }\end{array}$ \\
\hline B-1 & $12.75 \pm 0.24$ & $51.22 \pm 10.63$ & $7.06 \pm 0.05$ & $68.42 \pm 8.16$ & $133.83 \pm 1.29$ & $67.02 \pm 0.70$ & $0.06 \pm 0.00$ & $7.23 \pm 0.58$ & 1621 \\
\hline B-2 & $10.74 \pm 0.64$ & $814.45 \pm 201.21$ & $6.96 \pm 0.07$ & $40.57 \pm 18.91$ & $193.91 \pm 14.92$ & $96.95 \pm 7.46$ & $0.09 \pm 0.01$ & $\begin{array}{l}7.032 \\
\pm 0.59\end{array}$ & 1953 \\
\hline B-3 & $9.21 \pm 0.02$ & $310.73 \pm 252.37$ & $7.07 \pm 0.05$ & $55.43 \pm 15.62$ & $167.01 \pm 9.51$ & $83.49 \pm 4.81$ & $0.08 \pm 0.0$ & $4.81 \pm 0.27$ & 711 \\
\hline B-4 & $9.34 \pm 0.00$ & $594.29 \pm 56.11$ & $7.02 \pm 0.02$ & $73.66 \pm 6.30$ & $163.30 \pm 1.13$ & $81.61 \pm 0.54$ & $0.08 \pm 0.0$ & $6.90 \pm 0.23$ & 196 \\
\hline B-5 & $13.06 \pm 0.03$ & $426.79 \pm 27.64$ & $7.08 \pm 0.07$ & $77.51 \pm 1.22$ & $204.69 \pm 0.80$ & $102.41 \pm 0.49$ & $0.1 \pm 0.0$ & $6.79 \pm 0.11$ & 212 \\
\hline B-6 & $13.06 \pm 0.15$ & $354.56 \pm 44.24$ & $7.00 \pm 0.05$ & $76.38 \pm 8.82$ & $228.28 \pm 10.76$ & $114.13 \pm 5.41$ & $0.11 \pm 0.01$ & $6.85 \pm 0.64$ & 1005 \\
\hline B-7 & $11.85 \pm 0.02$ & - & $7.20 \pm 0.03$ & $26.08 \pm 6.38$ & $485.53 \pm 2.86$ & $242.73 \pm 1.41$ & $0.24 \pm 0.0$ & $7.94 \pm 0.38$ & 172 \\
\hline B-8 & $12.31 \pm 0.05$ & $412.32 \pm 236.02$ & $7.17 \pm 0.02$ & $-30.96 \pm 8.61$ & $470.09 \pm 44.96$ & $235.09 \pm 22.47$ & $0.23 \pm 0.02$ & $1.07 \pm 0.53$ & 206 \\
\hline B-9 & $15.2 \pm 0.12$ & $741.06 \pm 117.62$ & $7.33 \pm 0.01$ & $-24.40 \pm 2.19$ & $708.44 \pm 23.62$ & $354.24 \pm 11.84$ & $0.35 \pm 0.01$ & $3.12 \pm 0.77$ & 216 \\
\hline B-10 & $14.39 \pm 0.04$ & $652.11 \pm 22.01$ & $7.41 \pm 0.01$ & $-76.24 \pm 4.97$ & $859.56 \pm 19.34$ & $429.74 \pm 9.65$ & $0.43 \pm 0.01$ & $0.75 \pm 0.27$ & 135 \\
\hline B-11 & $14.95 \pm 0.08$ & $538.87 \pm 64.67$ & $7.40 \pm 0.01$ & $-114.84 \pm 21.55$ & $728.06 \pm 24.14$ & $364.04 \pm 12.08$ & $0.36 \pm 0.01$ & $0.49 \pm 0.25$ & 1275 \\
\hline B-12 & $14.78 \pm 0.06$ & $501.00 \pm 18.99$ & $7.41 \pm 0.01$ & $-64.27 \pm 5.30$ & $862.4 \pm 7.14$ & $431.12 \pm 3.56$ & $0.43 \pm 0.0$ & $5.52 \pm 0.33$ & 123 \\
\hline B-13 & $14.57 \pm 0.04$ & $574.19 \pm 21.60$ & $7.50 \pm 0.01$ & $-45.70 \pm 6.81$ & $917.39 \pm 14.09$ & $458.75 \pm 7.06$ & $0.46 \pm 0.01$ & $0.39 \pm 0.13$ & 122 \\
\hline B-14 & $13.78 \pm 0.12$ & $366.07 \pm 18.89$ & $7.56 \pm 0.01$ & $-71.93 \pm 16.23$ & $927.72 \pm 3.71$ & $463.84 \pm 1.89$ & $0.46 \pm 0.0$ & $6.38 \pm 0.43$ & 122 \\
\hline
\end{tabular}

that the water quality at the upstream site was less polluted due to treatment of water before discharging into the river. However, lack of enough wastewater treatment plants and direct connection of sewer lines and discharge of solid waste along the Bagmati River at the downstream site (from B-7 downward) enhanced organic waste and soluble conductive substances which consumed almost all DO, hence, ORP value of river water becomes negative.

\section{Temporal Variation of Water Quality Parameter of the Bagmati River}

Daily variation of water quality parameters at Shankhamul (before the confluence of tributaries) and Balkhu (after confluences of tributaries) sites was plotted in Fig. 5. Fig. 5 (a) shows that the $\mathrm{pH}$ of river water varied between 7.3 and 7.5 at Shankhamul and between 7.4 and 7.7 at the Balkhu site. The daily variation of conductivity (Fig. 5 b) in both Shankhamul and Balkhu sites was non-steady and it varied between 814 and $886 \mu \mathrm{S} / \mathrm{cm}$. The turbidity was very high (>600 FTU) at the Shankhamul site but that was comparatively low in the Balkhu site especially on first Day-1 (Fig. 5c). The dissolved oxygen at the Shankhamul site was almost zero on most of the days except Day-2 but it was more than 3 ppm at the Balkhu site on all days (Fig. 5d). ORP varied from day to day but the values were always negative in both sites (Fig. 5e). The ORP value was close to $-50 \mathrm{mV}$ at the Shakhamul site whereas it was mostly less than $-50 \mathrm{mV}$ at the Balkhu site. Results attributed that river water of both Shankhamul and Balkhu sites were extensively polluted permanently. The comparatively low DO and turbidity value at the Balkhu site may be because of the check dam erected below Balkhu Bridge. This is because aeration of water during flowing across the dam increased the concentration of DO and removed the suspended particles (Regmi 2013).

The diurnal variation of water quality parameters at the Shankhamul site showed that there were great variations of water quality parameters with time (Fig. 6). As expected, the temperature was $19^{\circ} \mathrm{C}$ at 9 am and increased linearly with time and peaked in the afternoon then decreased slowly in the evening (Fig. 6a). Similarly, pH and conductivity were 7.4 and about $600 \mu \mathrm{S} / \mathrm{cm}$ at 9 am and increased linearly to 7.6 and $850 \mu \mathrm{S} / \mathrm{cm}$, respectively at $10 \mathrm{pm}$ and remained almost constant till 2 pm and decreased slowly again (Fig. 6b). Interestingly, the DO and ORP value changed differently than as expected in normal condition (Fig. 6c). Both concentrations were high in the morning indicating cleanness of water, however, it decreased continuously with time in the day. The observation was conducted before the confluence of tributaries. Hence, the enhancement of pollutants in the daytime was considered to be due to the effect of human activity i.e., the discharge of domestic and industrial effluent into the river water rather than mixing of tributaries. The DO was as high as 8 ppm at 9:00 am and decreased to almost zero after 11:30 am. Generally, the dissolved oxygen increases in the daytime 


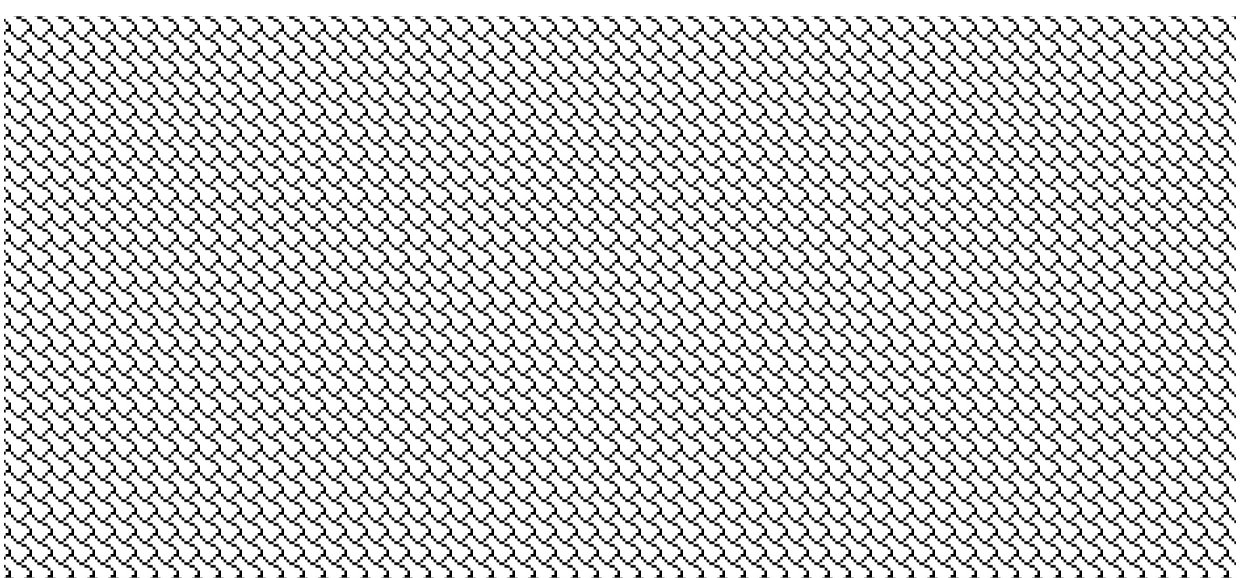

Sample number
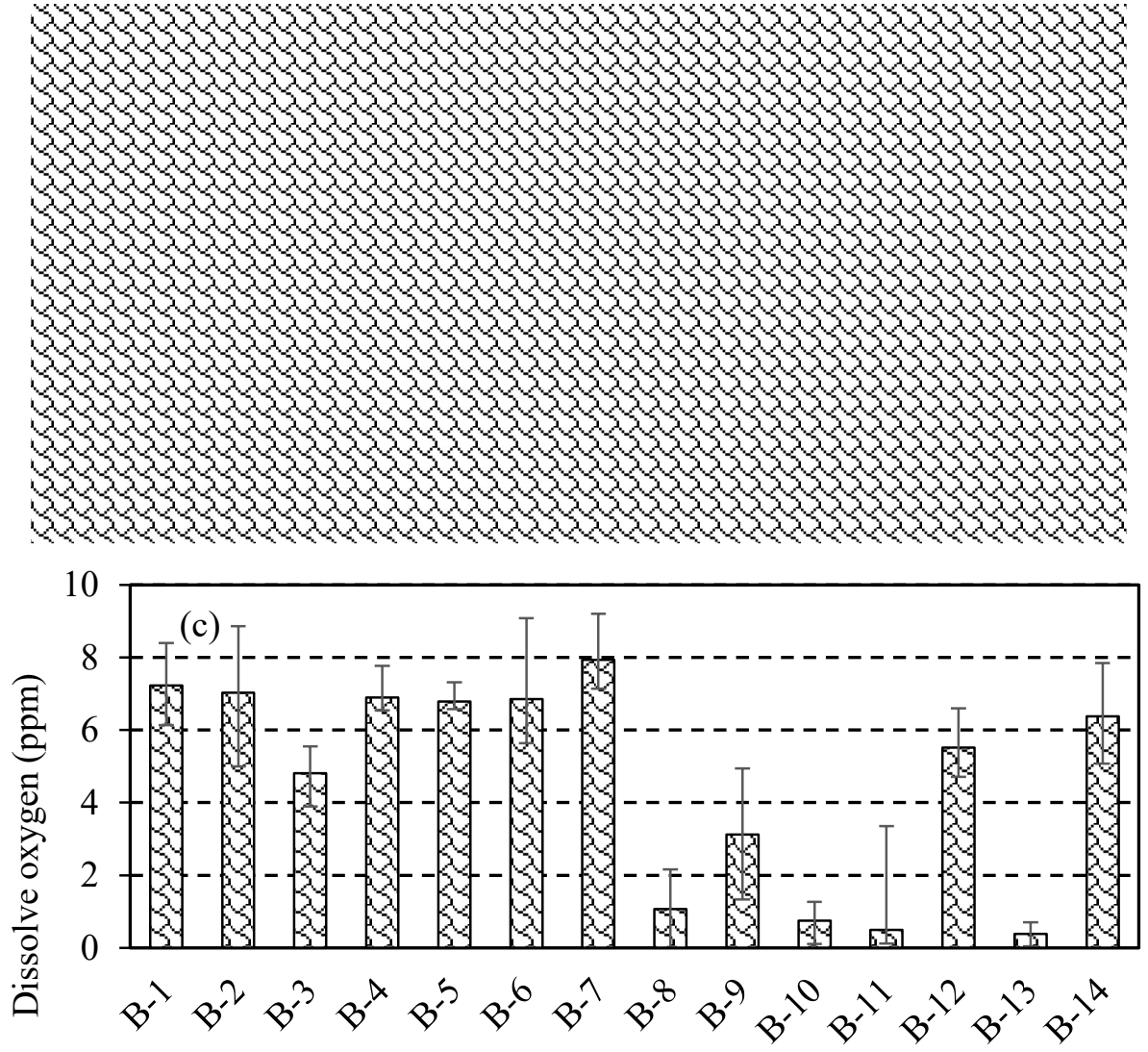

Sample number

Fig. 4: Spatial variation of (a) Conductivity, (b) Oxidation Reduction Potential (ORP), and (c) Dissolve Oxygen (DO) along the Bagmati River.

due to the photosynthetic activity of plants and algae present in the river water (Martinez-Tavera et al. 2017). The tendency of DO concentration attributed that instead of enhancement of DO by photosynthesis it was used by microorganisms originated from wastewater to decompose the organic matter present in the river water. ORP was positive and about 50
$\mathrm{mV}$ initially and decreased linearly to $-80 \mathrm{mV}$ at $14: 00$. The high ORP value in the morning indicated that there was the presence of an oxidizing agent but enhancement of a reducing agent such as ammonia, nitrites, organic substances reduced ORP value in the daytime (Goncharuk et al. 2010). From the result, it is considered that human activities enhanced 

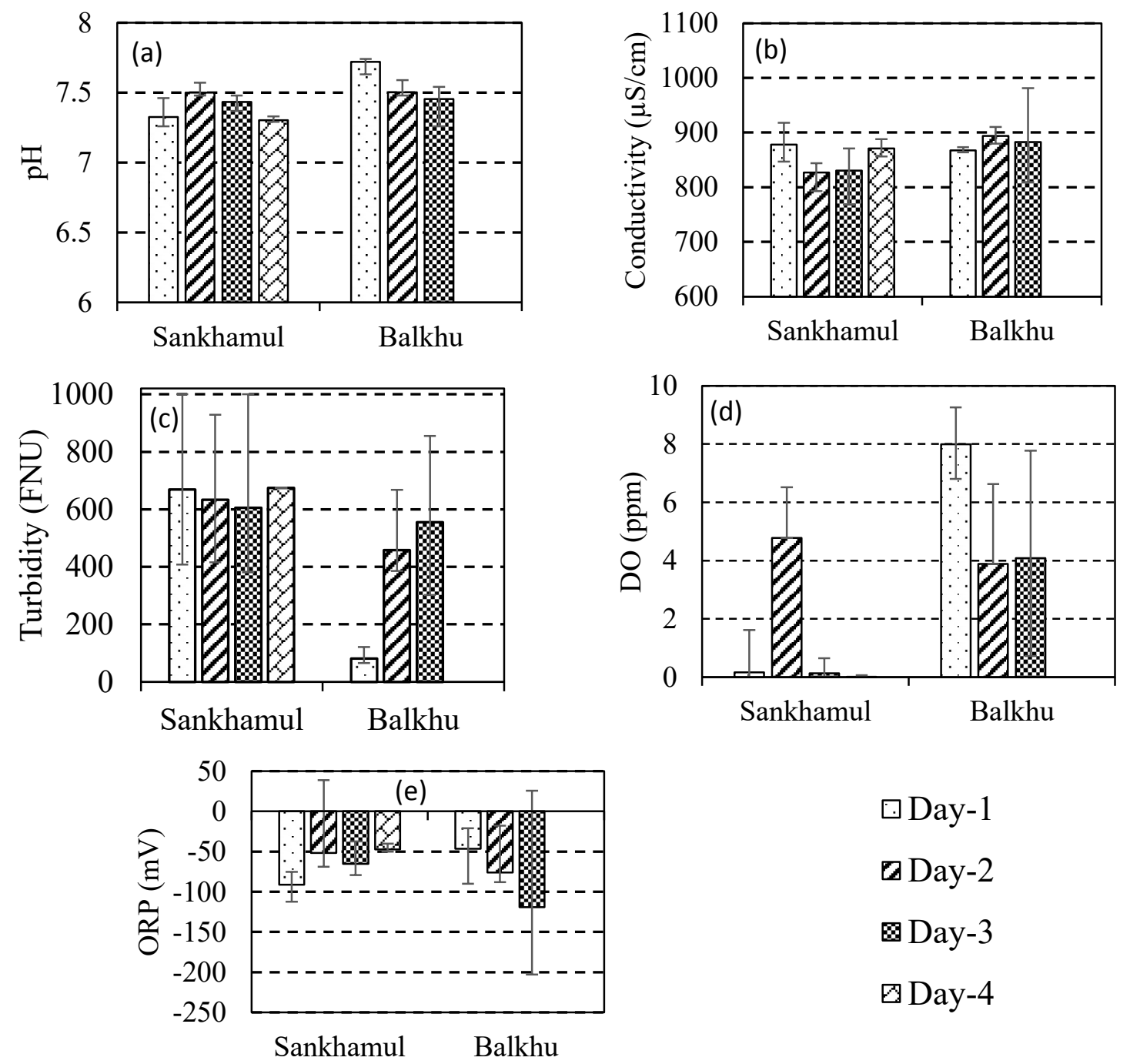
$\bullet$ Day-1
Day-2
Day-3
囚Day-4

Fig. 5: Daily variation of water quality parameters (a) pH, (b) conductivity, (c) turbidity, (d) DO and (e) ORP at Shankhamul and Balkhu sites.

pollutants extremely at the daytime which consume almost all DO producing an anoxic condition in the river water at the downstream site (AliAl-Samawi \& Al-Hussaini 2016).

\section{Real-Time Fine-Scale Variation of Water Quality Parameters Along the Bagmati River}

Real-time fine-scale spatial variations of water quality parameters along the Bagmati River from a mobile tracer system were plotted in Fig. 7. The heat map (Fig. 7) insights interesting results of water quality parameters in space domains. The temperature during the observation period was recorded between 20.64 and $22.34^{\circ} \mathrm{C}$. The temperature range suggested that the effect of temperature on water quality parameters was insignificant. The $\mathrm{pH}$ was slightly alkaline (7.28 \pm 0.041$)$ and varied between $\mathrm{pH} 7.18$ to 7.39 , therefore variation of $\mathrm{pH}$ was less pronounced in the heat map (Fig. 7a). Fig. 7b shows that the conductivity enhanced slowly towards the downflow till the Bishnumati tributary and sharply enhanced after mixing it and continuously enhanced till the end of the observation site. Initially, the conductivity was about $700 \mu \mathrm{S} / \mathrm{cm}$ but it enhanced to more than $800 \mu \mathrm{S} / \mathrm{cm}$ downstream. The effect of tributaries on conductivity was clearly observed. The enhancement of conductivity after mixing with the Manohara, Dhobikhola, and Tukuchakhola tributaries was insignificant but that was significant after mixing with the Bishnumati and Balkhukhola tributaries (Fig. 7b). The variation of turbidity along the river was just opposite to that of $\mathrm{pH}$ and conductivity (Fig. 7c). The turbidity was high initially from Shankhamul to Thapathali and decreased slowly along the downstream. Visibly decreased 

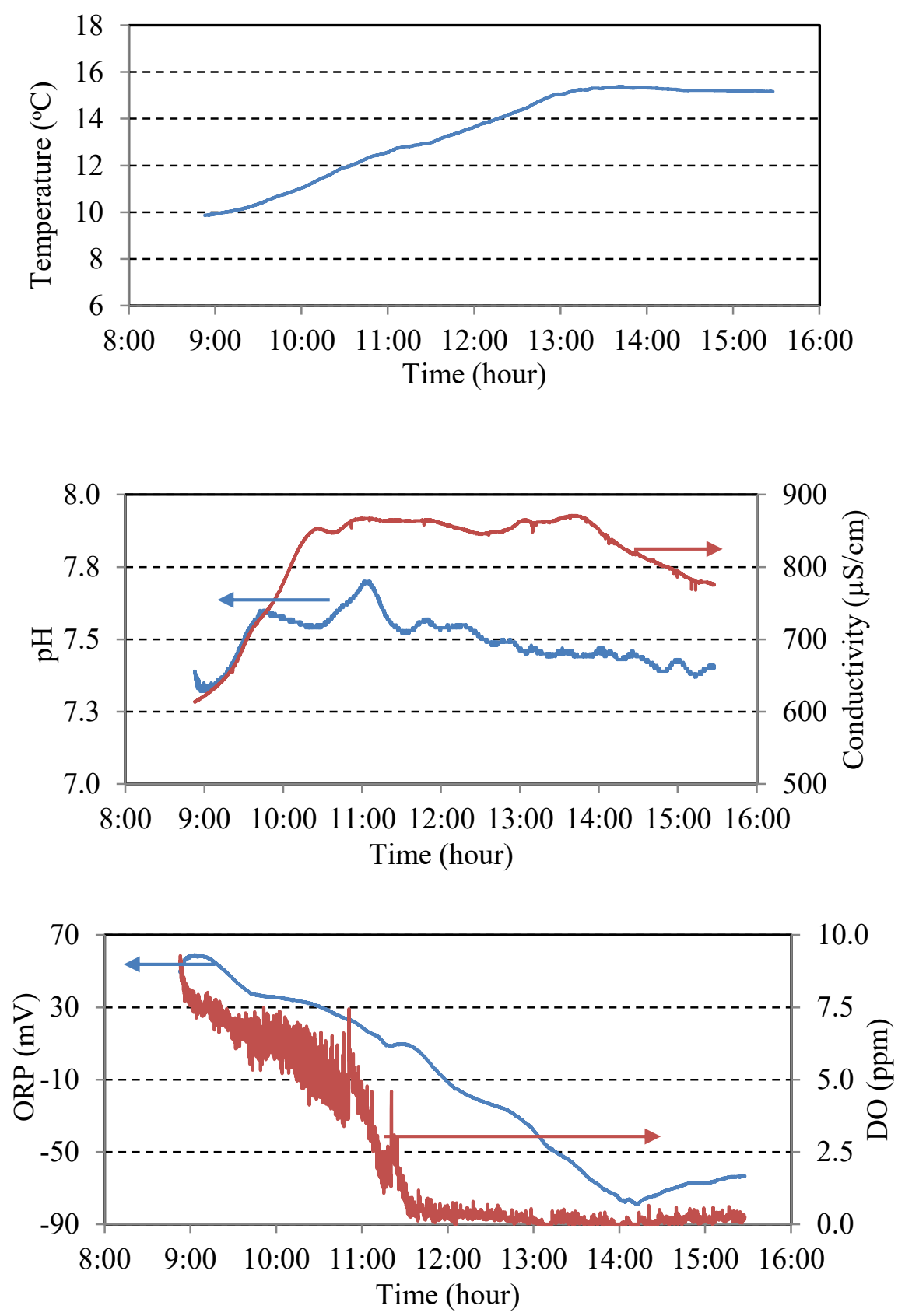

Fig. 6: Diurnal variation of water quality parameters (a) Temperature (b) $\mathrm{pH}$ and conductivity (c) ORP and DO at Shankhamul site.

turbidity near the end of the observation site illustrates the possibility of either decomposition or settlement of macromolecules during flowing. The photograph of river water taken at a different point (Fig. 7d) also indicated that the color of river water was unlike from point to point. The color was comparably dark downstream than that at the Shankhamul site and was extremely black at the Sundarighat site. Previous studies also reported that the turbidity was low but the color of the water was darkest downstream near the Sundarighat (at Jalbinayak) (Adhikari et al. 2019).

There was a consistency of spatial variations of DO concentration (Fig. 7e) and ORP (Fig. 7f). The DO concentration was low in between Shankhamul and Thapathali site and suddenly enhanced after Thapathali site and again decreased continuously to zero till the end, slight increment at Balkhu Bridge was observed but it was less pronounced. The fixed 
station data (Fig. 4c) also indicated that the dissolved oxygen was high at B-12 (nearby Thapathali) and B-14 (Balkhu) sites. Similarly, the ORP value was negative along the river except just after Thapathali $(50 \mathrm{mV})$ where DO content was around 7 ppm (Fig. 7e). The enhancement of DO and ORP values at the Thapathali site was may due to the presence of a check dam under the Bagmati bridge at Thapathali. As discussed previously, the dam retains a large amount of river water and spread throughout the riverbank, further, falling water from the dam hits the surface. Both these processes help to dissolve atmospheric oxygen causing aerobic conditions (Regmi 2013). The ORP value varied between -100 and $-263 \mathrm{mV}$ and the lowest ORP value was observed near the Suhdarighat Bridge. Suslow (2004) and Ali Al-Samawi (2016) reported that negative ORP $(<250 \mathrm{mV})$ is a critical event in an anaerobic digester, where the sulfide serves as a
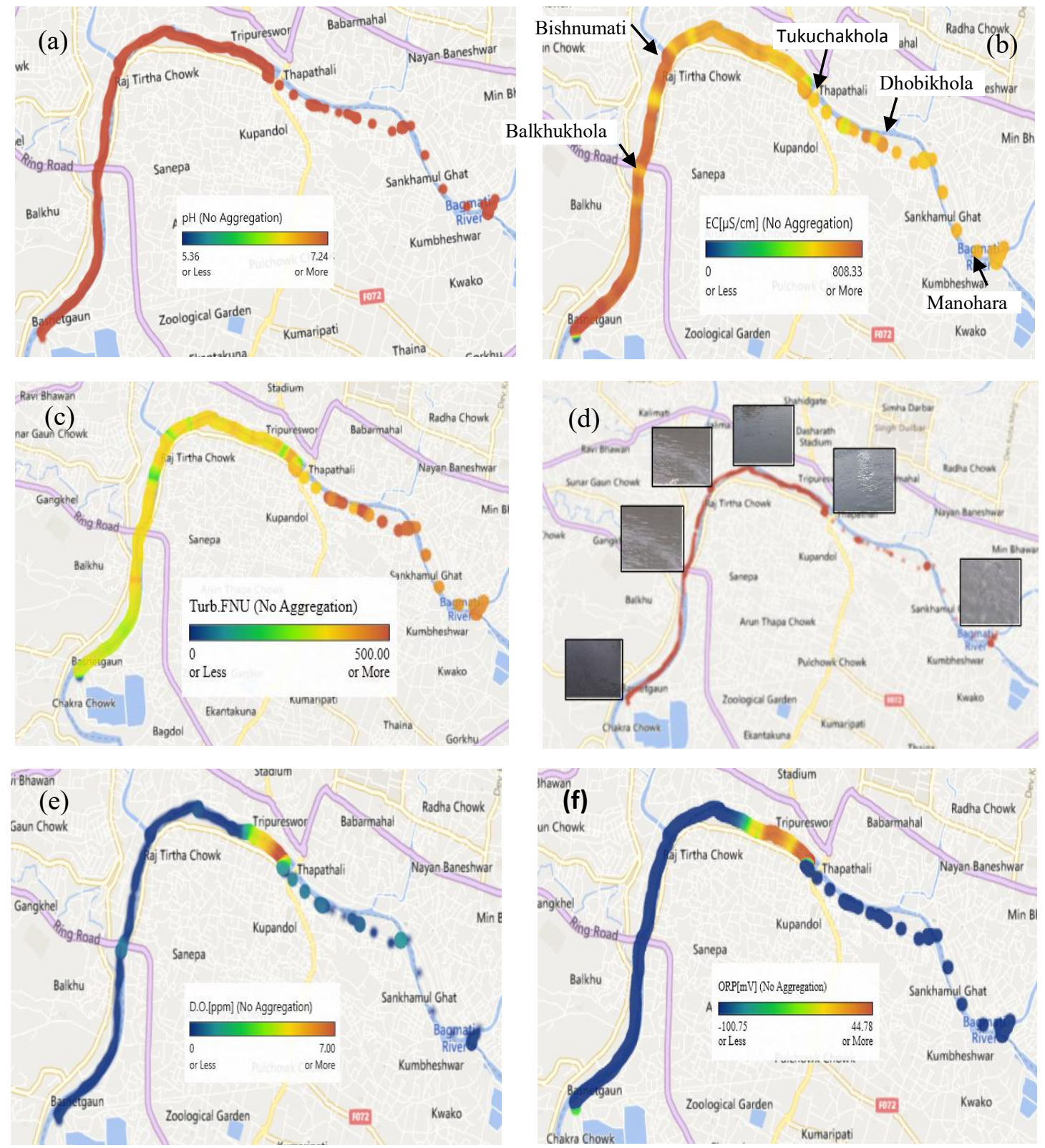

Fig. 7: Micro-scale spatial variation of water quality parameters (a) pH, (b) conductivity (c) turbidity (d) photograph of water (e) DO and (f) ORP along the Bagmati River. 
sulfur nutrient for anaerobic and anaerobic bacteria, which produces a large variety of volatile compounds, where many of these volatile compounds are malodorous. The results suggested that the collection of pollutants along the river during downflow and connection of pipeline of untreated wastewater and dumping of solid waste near the Sundarighat area might be responsible for the production of a huge amount of sulfate-containing pollutants in the river water (Regmi 2013). These sulfate-containing compounds turned into acid and methane at the anaerobic condition which forms dark black sediment and generates malodorous volatile compounds (Castro \& Huber 2005). This is the reason for black-colored water with stinky odor observed along the Bagmati River downstream. During the observation time, the research team observed a stinky smell at the Sundarighat bridge which made it difficult to stand over the bridge even for a few minutes. From the results of fine-scale real-time data, it was confirmed that human activities such as solid waste disposal along the bank of the river and direct discharge of sewer and mixing of polluted tributaries tremendously enhanced the pollutants (Kannel et al. 2007, Adhikari \& Sah 2017) that turned out Bagmati River into a biologically dead river.

\section{CONCLUSIONS}

The water quality parameter of the Bagmati River in Kathmandu Valley was characterized using real-time data. The dissolved oxygen (DO) content was more than $5 \mathrm{ppm}$ at upstream from Gokarna to Tilganga sites which was enough to oxidize organic compound. However, the dissolved oxygen content decreased to almost zero downstream from Tinkune to Balkhu sites indicating less chances of survival for the living organisms. Immense change of water quality parameters before mixing with the tributaries was the indication of mixing of untreated domestic and industrial wastewater into the Bagmati River from urban industrialized areas. The diurnal variation of water quality parameters at the Shankhamul site showed an amazing trend. The increase in $\mathrm{pH}$ and conductivity but the decrease in ORP and DO in the daytime suggested that the activity of people in the daytime was responsible to convert pristine water to perilous river water.

The real-time fine-scale space domain data indicated that pollutants increased continuously along the downflow of the river. Likely polluted tributaries enhanced the conductivity of Bagmati River instead of dilution. DO concentration was almost zero and ORP decreased from -100 to $-263 \mathrm{mV}$ at the end of the observation site. The results attributed that the solid waste, domestic sewer as well as tributaries loaded sulfur-containing organic pollutants reduced molecular oxygen to such an extent that living organisms could not survive in it. In absence of oxygen, the decomposition of pollutants by microorganisms generated volatile substances, which was responsible for the hazardous fouling smell along the bank of the river.

\section{ACKNOWLEDGEMENTS}

The authors are grateful to the University Grant Commission (UGC), Nepal for supporting us with faculty research grants. We are very much thankful to Mr. Ram Prasad Rimal and Mr. Laxman Prasad Rimal, RamLaxman Innovations, Lazimpat for providing us with an expertized technical support. Thanks are due to Mausam Khanal, Nepal River Conservation Trust for providing support with the river rafting arrangements. We kindly acknowledge Mr. Biplab Bhudhathoki, Mr. Sushant Gautam, and Mr. Janak Bhatta, Tribhuvan University for lending their supports in the observations.

\section{REFERENCES}

Adhikari, M.P. and Sah, M.K. 2017. Chlorine Demand and water pollutants of pond and river water. J. Nepal. Chem. Soc., 36: 39-48.

Adhikari, M.P., Neupane, M.R. and Kafle, M. 2019. Physio-chemical parameterization and determination of the effect of tributaries on the enhancement of pollutants in Bagmati River. J. Nepal Chem. Soc., 40: $36-43$.

Aggarwal, R. and Arora, S. 2012. A study of water quality Kaushalya River in the submountaneous Shivalik region. Int. J. Sci. Technol. Res., 1(8): 52-68.

AliAl-Samawi, A.A. and Al-Hussaini, S. N. H. 2016. The oxidation-reduction potential distribution along Diyala river within Baghdad city. Mesop. Environ. J. 2(4): 54-66.

Bajracharya, S.B. 2014. Bagmati Action Plan (2009-2014), 2009 Government of Nepal \& National Trust for Nature Conservation Khumaltar, Lalitpur, Nepal ISBN No. 978-993933933-702:8-4.

Castro, P. and Huber, M.E. 2005. Marine Biology ( $5^{\text {th }}$ ed.) McGraw Hill, New York.

Costa, J.S., Braga, F.S., Almeida, R.S., Ramos, D.C., Brito, A.C., Cunha, C. and Santos, B. R. 2015. Physicochemical characterization of water quality-Lagoa dos Indios in Bacapa, Brazil. J. of Amer. Chem. Sci., 5(2): 122-134.

Goncharuk, V.V., Bagrii, V.A., Mel'nik, L.A., Chebotareva, R.D. and Bashtan, S.Y. 2010. The use of redox potential in water treatment processes. J. of Water Chem. Technol. 32(1): 1-9

Green, H.M. 2003. The effects of carpet dye on the Bagmati River. Masters of Engineering Thesis. Massachusetts Institute of Technology, Cambridge, Massachusetts, USA.

Kannel, P.R., Lee, S., Kanel, S.R., Khan S.P. and Lee, Y.S. 2007. Spatial-temporal variation and comparative assessment of water quality of urban river system: A case study of the river Bagmati (Nepal). Environ. Monit. Assess., 129: 433-459.

Mahmud, N.S., Abdullah, S.Z., Jalal, K.C.A., Rimatulhana, R. and Amal, M.N. 2019. Assessment of bacteria and water quality parameters in cage cultured Pangasius hypophthalmus in Temerloh, Pahang River, Malaysia. Nat. Env. \& Poll. Tech., 18(5).

Malla, R., Shrestha S., Chapagain S.K., Shakya, M. and Nakamura, T. 2015. Physio-chemical and oxygen-hydrogen isotopic assessment of Bagmati and Bishunumati rivers and the shallow groundwater along the river corridors in Kathmandu Valley, Nepal. J. of Water Res. Prot., 7: 1435-1448.

Martinez-Tavera, E., Rodriguez-Espinosa, P.F., Shruti, V.C., Sujitha, S.B., 
Morales-Garcia, S.S. and Munoz-Sevilla, N.P. 2017. Monitoring the seasonal dynamics of physicochemical parameters from Atoyac River Basin (Puebla), Central Mexico: Multivariate approach. Environ. Earth Sci., 76: 95.

McCarthy, M., Scott, C., Ensink, J., Jiang, B. and Biggs, T. 2008. Salinity implications of wastewater irrigation in the Musi River catchment in India. Cey. J. Sci. (Bio. Sci.)., 37(1): 49-59.

Mehta, K.R. and Rana, S.V.S. 2017. Study of physico-chemical parameters of Bagmati River, Kathmandu, Nepal. Int. J. of Chem. Stud., 5(6): 2042-2048

Milner, C., Basnet, H., Gurung, S., Maharjan, R., Neupane, T., Shah, D.N., Shakya, B.N., Tachamo, R., Shah, R.D and Vaidya, S. 2015. Bagmati river expedition 2015: A baseline study along the length of the Bagmati River in Nepal to gather data on physical, chemical, and biological indicators of water quality and pollution, and document human-river interaction. Nepal River Conservation Trust and Biosphere Association. Kathmandu, Nepal.

Mishra, B.K., Regmi, R.K., Masago, Y., Fukushi, K., Kumar, P. and Sarawat, C. 2017. Assessment of Bagmati River pollution in Kathmandu Valley: Scenario-based modeling and analysis for sustainable urban development. Sust. Water Qual. Ecol., 9: 67-77.

Okeke, P.N. and Adinna, E.N. 2013. Water quality study of Ontamiri River in Owerri, Nigeria. Uni. J. of Environ. Res. Technol. 3(6): 641-649.

Paudyal, R., Kang, S., Sharma, C.M., Tirpathee, L. and Sillanpaa, M. 2016. Variations of the physicochemical parameters and metal levels and their risk assessment in urbanized Bagmati river, Kathmandu, Nepal. J. of Chem., 1-13.

Pratum, C., Arunrat, N., Sereenonchai, S., Huang, J.C. and Xu, T. 2019. Water quality situation of the Tha Chin river and the riverbank community's understanding. Nat. Env. and Poll. Tech., 18(3): 1045-1051.
Regmi, S. 2013. Wastewater treatment in Khatmandu: management, treatment, and alternative. Bachelor's Thesis. Mikkeli University of Applied Science, Finland.

Sharma, C.M., Kang, S., Tripathee, L., Paudyal, R. and Sillanpāā, M. 2020. Major ions and irrigation water quality assessment of the Nepalese Himalayan rivers. Environ. Develop. and Sust., 23: 2668-2680.

Shrestha, N., Regmi, R.K. and Mishra, B.K. 2015. Current status of water environment in Kathmandu Valley, Nepal. Water and Urban Initiative Working Paper Series-3: 1-5.

Shrestha, P. and Tamrakar, N.K. 2012. Morphology and classification of the main stem Bagmati River, Central Nepal. Bull. Depart. Geol.., 15: 23-34.

Sundararajan, S., Kamalakannan, B., Karthikeyan, R., Khadangaand, M.K. and Jena, B.K. 2018. Diurnal variation and water quality parameters of three different ecosystems in the Gulf of Mannar, Southeast Coast of India. 2018. J. Marine Sci. Res. Dev., 8(3): 1-6.

Suslow, T. V. 2004. Oxidation-deduction potential for water disinfection monitoring, control, and documentation. UC Agric. Nat. Resour. ANR Pub., 8: 1-5.

Tripathee, L., Kang, S., Sharma, C.M., Rupakheti, D., Paudyal, R., Huang, J. and Sillanapāā. 2016. Preliminary health risk assessment of potentially toxic metals in surface water of the Himalayan Rivers, Nepal. Bull. Environ. Contam. Toxicol., 97: 855-862.

Weather Nepal. 2020. The temperature of Kathmandu on Dec 2019 and Jan 2020 (Retrieved on Mar 28, 2020. https://www.timeanddate.com/ weather/nepal $/$ kathmandu/historic?month $=1 \&$ year $=2020$

Wolfe, A.N.C. 2000. Microbial contamination in the Kathmandu valley drinking water supply and Bagmati river. Master of Eng. Thesis. Civil and Environ Eng. Dep. Massachusetts Ins. of Techno. Cambridge, Massachusetts, USA. 